\title{
PENGGUNAAN ANALISIS ABC UNTUK PENGENDALIAN PERSEDIAAN BARANG HABIS PAKAI : STUDI KASUS DI PROGRAM VOKASI UI
}

\author{
Titis Wahyuni \\ Laboratorium Akuntansi, Program Vokasi UI, t.wahyuni@ui.ac.id
}

\begin{abstract}
Diterima : 13 April 2015
Layak Terbit : 13 Mei 2015

Abstrak

Tujuan penelitian ini adalah untuk mengetahui pengendalian persediaan barang habis pakai yang diterapkan di Program Vokasi Universitas Indonesia serta untuk mengetahui persediaan barang habis pakai yang menjadi kelompok A, B, dan C berdasarkan analisis ABC pemakaian, investasi, dan indeks kritis. Penelitian ini menggunakan pendekatan deskriptif analitis untuk melihat permasalahan yang dihadapi dan aktivitas yang dilakukan oleh Bagian Pengadaan Program Vokasi UI dalam mengelola persediaan barang habis pakai selama tahun 2014. Data barang persediaan habis pakai diolah untuk memberikan gambaran mengenai pola persediaan barang habis pakai kemudian dengan metoda klasifikasi ABC dilakukan analisis permintaan, investasi, dan indeks kritis. Penelitian ini juga akan menghasilkan aplikasi yang digunakan untuk mengelola persediaan barang habis pakai di Program Vokasi UI. Hasil dari penelitian ini adalah pengendalian terhadap persediaan barang habis pakai di Program Vokasi UI sudah cukup memadai. Dari hasil analisis ABC permintaan didapat bahwa kategori persediaan barang habis pakai yang masuk dalam kelompok A adalah sebanyak 9 item, kelompok B sebanyak 26 item, dan kelompok C sebanyak 125 item. Sebanyak 78,74\% permintaan berasal hanya dari 9 item barang dan 5,11\% permintaaan berasal dari 125 item barang. Dari hasil analisis $\mathrm{ABC}$ nilai investasi didapat bahwa kategori persediaan barang habis pakai yang masuk dalam kelompok A adalah sebanyak 18 item, kelompok B sebanyak 29 item, dan kelompok C sebanyak 113 item. Sebanyak 79,94\% nilai investasi hanya diberikan untuk 18 item barang dan 5,01\% nilai investasi diberikan untuk 113 item barang. Dari hasil analisis ABC indeks kritis didapat bahwa sebanyak 11 item persediaan barang habis pakai yang masuk kelompok A memiliki nilai investasi sebesar 79,94\%, 67 item persediaan barang habis pakai yang masuk kelompok B memiliki nilai investasi sebesar $15,06 \%$, dan 82 item persediaan barang habis pakai yang masuk kelompok C memiliki nilai investasi sebesar 5,01\%.
\end{abstract}

Kata Kunci: persediaan barang habis pakai, Analis ABC, indeks nilai kritis

\begin{abstract}
The purpose of this study was to determine the consumable inventory control are applied in Vocational Education Program, University of Indonesia as well as to determine the consumable inventory into groups $\mathrm{A}, \mathrm{B}$, and $\mathrm{C}$ based on the use of the $\mathrm{ABC}$ analysis, investing, and the critical index. This research uses descriptive analytical approach to look at the problems faced and the activities undertaken by the Procurement Section vocational program UI to manage inventory of consumable during 2014. The supply of consumable goods data is processed to provide a picture of the pattern of inventory consumable goods then the classification method $\mathrm{ABC}$ analysis of demand, investment, and the critical index. This research will also produce an application used to manage the supply of consumables in the vocational program UI. Results from this study is the control of the supply of consumables in the vocational program UI is sufficient. ABC analysis of the results obtained that the demand for consumables inventory categories are included in the group A are as many as nine items, group B were 26 items, and group C as many as 125 items. A total of $78.74 \%$ of the demand comes only 9 items and $5.11 \%$ request came from 125 items of goods. ABC analysis of the results obtained that the investment value of inventory categories consumables are included in the group A are as many as 18 items, group B a total of 29 items, and group C as many as 113 items. A
\end{abstract}


total of $79.94 \%$ of investment value is only given to 18 items and $5.01 \%$ of investment value given for 113 items. From the analysis of the critical index ABC found that as many as 11 items of inventory consumable goods that enter the group A has an investment of $79.94 \%, 67$ inventory items consumable goods that enter the group B has an investment of $15.06 \%$, and 82 items supply of consumable goods that enter the group $\mathrm{C}$ has an investment value amounting to $5.01 \%$.

Keywords: supply of consumables, $\mathrm{ABC}$ analyst, critical value index.

\section{PENDAHULUAN}

\section{Latar Belakang}

Salah satu penentu kelancaran kegiatan belajar mengajar adalah tersedianya alat tulis kantor (persediaan barang habis pakai) yang cukup. Keberhasilan kegiatan belajar mengajar sangat dipengaruhi oleh ketersediaan dan kecukupan alat tulis kantor. Kurangnya jumlah perse-diaan alat tulis kantor dapat menyebabkan kegiatan belajar mengajar terganggu yang pada akhirnya kompetensi yang sudah ditetapkan untuk setiap mata ajar tidak dapat tercapai. Sebaliknya, kelebihan persediaan alat tulis kantor dapat menyebabkan pemborosan.

Program Vokasi UI sudah menggunakan sistem untuk mengelola persediaan barang yang diperoleh dari Universitas Indonesia (SIMAK Persediaan) dan digunakan di seluruh fakultas, program studi serta lembaga yang ada di Universitas Indonesia. Akan tetapi sistem ini hanya digunakan untuk mencatat persediaan barang yang masuk dan keluar saja dan tidak dapat memberikan informasi tentang barang yang paling banyak dibutuhkan, barang yang tidak banyak dibutuhkan, berapa banyak permintaan setiap pengguna dan siapa saja pengguna yang paling banyak melakukan permintaan barang di Program Vokasi UI. Padahal, informasi tentang hal-hal tersebut sangat dibutuhkan oleh Program Vokasi untuk mengelola persediaannya. Selain itu pengendalian terhadap setiap jenis barang masih dilakukan dengan cara yang sama. Hal ini disebabkan belum diterapkannya pengendalian barang berdasarkan Analisis ABC. Untuk menentukan ketersediaan barang harus dilakukan pencatatan secara manual kemudian dilakukan stock opname setiap bulan untuk mencocokkan jumlah persediaan yang terdapat pada catatan manual dan jumlah fisik barang di tempat penyimpanan.

Salah satu aspek dari manajemen persediaan yang penting adalah mengklasifikasikan item-item persediaan barang habis pakai. Pengklasifikasian ini bertujuan untuk mengetahui priopritas tiap kelompok item persediaan agar dapat menerapkan strategi pengelolaan persediaan yang sesuai dengan karakteristik persediaan (Nurul, Mahendrawathi, dan Kusumawardani, 2011). Analisis ABC adalah salah satu metode yang biasa digunakan untuk pengklasifikasian persediaan.

Analisis ABC adalah adalah metode pengklasifikasian barang berdasarkan peringkat nilai dari nilai tertinggi hingga 
terendah, dan dibagi menjadi 3 kelompok besar yang disebut kelompok A, B dan C. Analisis $\mathrm{ABC}$ dapat membantu manajemen menentukan pengendalian yang tepat untuk masing-masing klasifikasi barang dan menentukan barang mana yang harus diprioritaskan untuk meningkatkan efisiensi dan mengurangi biaya. Selain analisis ABC terdapat pula analisis indeks kritis yang digunakan untuk mengetahui persediaan barang mana saja yang tergolong kritis yang berarti barang tersebut harus selalu tersedia (Pawitan dan Paramasatya, 2006).

Berdasarkan permasalahan di atas, tujuan dari penelitian ini adalah: (1) Mengetahui pengendalian persediaan barang di Program Vokasi Universitas Indonesia. (2) Mengetahui barang persediaan yang menjadi kelompok kelompok A, B, dan C berdasarkan analisis $\mathrm{ABC}$ pemakaian, investasi, dan indeks kritis.

Pengendalian Persediaan

Organisasi harus mengelola persediaannya dengan baik sehingga memiliki ketersediaan dan kecukupan persediaan pada saat diperlukan oleh pengguna. Untuk dapat mengelola persediaan agar dapat memenuhi kebutuhan jumlah persediaan pada waktu yang tepat serta jumlah biaya yang rendah, maka diperlukan sistem pengendalian persediaan yang baik.

Menurut Sofyan Assauri (1999), pengendalian persediaan adalah suatu kegiatan untuk menentukan tingkat dan komposisi dari suatu persediaan, suku cadang, barangbaku, dan barang hasil atau produksi, sehingga perusahaan dapat melindungi kelancaran produksi dan penjualan serta kebutuhan pembelanjaan perusahaan dengan efektif dan efisien.

\section{Analisis ABC}

Analisis ABC adalah adalah metode pengklasifikasian barang berdasarkan peringkat nilai dari nilai tertinggi hingga terendah, dan dibagi menjadi 3 kelompok besar yang disebut kelompok A, B dan C.

Analisis ABC membagi persediaan yang menjadi tiga kelas berdasarkan besarnya nilai (value) yang dihasilkan oleh persediaan tersebut (Schroeder, 2010). Analisis ABC merupakan aplikasi persediaan yang menggunakan prinsip pareto. Prinsip ini menyatakan bahwa "critical view and trivial many". Prinsip ini mengajarkan untuk memfokuskan pengendalian persediaan kepada jenis persediaan yang bernilai tinggi atau kritikal daripada yang bernilai rendah atau trivial. Menurut Schroeder (2010), klasifikasi ABC adalah sebagai berikut:

1. Kelas A merupakan barang-barang yang memberikan nilai yang tinggi. Walaupun kelompok A ini hanya diwakili oleh 20\% dari jumlah persediaan yang adatetapi nilai yang diberikan adalah sebesar $80 \%$.

2. Kelas B merupakan barang-barang yang memberikan nilai sedang. Kelompok persediaan kelas B ini diwakili oleh 30\% dari jumlah persediaan dan nilai yang dihasilkan adalah sebesar $15 \%$.

3. Kelas C merupakan barang-barang yang memberikan nilai yang rendah. Kelompok persediaan kelas $\mathrm{C}$ diwakili oleh $50 \%$ dari total persediaan yang ada dan nilai yang dihasilkan adalah sebesar 5\%. 
Analisis ABC dapat membantu manajemen dalam menentukan pengendalian yang tepat untuk masing-masing klasifikasi barang dan menentukan barang mana yang harus diprioritaskan untuk meningkatkan efisiensi dan mengurangi biaya.

Untuk melakukan analisis $\mathrm{ABC}$ dengan satu kriteria maka dapat dilakukan langkahlangkah sebagai berikut:

\section{Analisis Pemakaian}

1. Mendaftar semua item yang akan diklasifikasi, beserta dengan data rata-rata pemakaian item logistik per tahun dan data rata-rata harga untuk setiap itemnya.

2. Mengalikan rata-rata pemakaian per tahun dengan rata-rata harga untuk setiap item untuk mendapatkan nilai penggunaan per tahun tiap item.

3. Mengurutkan nilai penggunaan per tahunnya mulai dari yang terbesar hingga yang terkecil. Jumlahkan secara kumulatif nilai penggunaan per tahunnya.

4. Mengkonversikan jumlah kumulatif tiap item menjadi prosentase kumulatif. Prosentase inilah yang menjadi ukuran item dalam menentukan kelompok item tersebut.

Analisis klasifikasi ABC memiliki beberapa manfaat, diantaranya sebagai berikut:

- Membantu manajemen dalam menentukan tingkat persediaan yang efisien.

- Memberikan perhatian pada jenis persediaan utama yang dapat memberikan cost benefit yang besar bagi perusahaan.
- Dapat memanfaatkan modal kerja (working capital) sebaik-baiknya sehingga dapat memacu pertumbuhan perusahaan.

- Sumber-sumber daya produksi dapat dimanfaatkan secara efisien yang pada akhirnya dapat meningkatkan produktifitas dan efisiensi fungsi-fungsi produksi.

\section{Analisis Investasi}

1. Menghitung jumlah pemakaian per tahun untuk setiap satuan unit barang.

2. Membuat daftar harga dari setiap barang tersebut.

3. Mengalikan pemakaian dengan harga setiap barang untuk mendapatkan nilai investasi.

4. Mengurutkan nilai investasi dari yang terbesar hingga terkecil, setelah itu membuat persentase nilai investasi.

5. Menghitung nilai investasi kumulatif.

6. Mengelompokkan barang persediaan berdasarkan persentase nilai kumulatif.

7. Jika nilai frekuensi kumulatifnya o sampai dengan $80 \%$ maka dikelompokkan sebagai A. Apabila berkisar antara $80-95 \%$ akan dikelompokkan sebagai $\mathrm{B}$, dan apabila berkisar antara $95-100 \%$ akan dikelompokkan sebagai C.

\section{Analisis ABC indeks kritis}

Analisis ini biasa digunakan dalam penelitian yang terkait dengan obat-obatan tetapi telah digunakan oleh Pawitan dan Paramasatya pada tahun 2006 dalam penelitian mereka yang berjudul Aplikasi Analisis Pareto Dalam Pengendalian Inventori BarangBaku pada Bisnis Restoran. Hal yang sama akan 
digunakan oleh penulis dalam melakukan penelitian ini. Analisis $\mathrm{ABC}$ indeks kritis dikembangkan oleh rumah sakit Universitas Michigan (Calhoun dan Campbell, 1885).

Analisis $\mathrm{ABC}$ indeks kritis mencakup jumlah pemakaian, nilai investasi, dan kritisnya terhadap pelayanan pengguna. Nilai kritis barang habis pakai terhadap pengguna ini akan dinilai oleh pengguna lain yang nantinya akan digunakan untuk menetapkan persediaan barang habis pakai dengan kategori A, B, dan C. Menurut Calhoun dan Campbell (1985), nilai persediaan akan dinilai oleh pengguna lain berdasrkan kriteria:

- Kelompok X, bila barang tersebut tidak boleh diganti dan harus selalu ada dalam proses pelayanan terhadap pengguna

- Kelompok Y, bila barang dapat disubstitusi dengan yang lain, walaupun tidak memuaskan seperti yang asli dan kekosongan kurang dari 48 jam dapat ditoleransi.

- Kelompok Z, bila barang dapat diganti dan kekosongan lebih dari 48 jam dapat ditoleransi.

- Kelompok O, bila barang tidak dapat diklasifikasikan dalam kelompok X,Y,Z

Langkah selanjutnya adalah setiap kelompok diberi bobot, yaitu : $\mathrm{X}=3, \mathrm{Y}=2, \mathrm{Z}=1$. Nilai kritis didapat dengan cara semua bobot yang diberikan pengguna barang dijumlah dan dibagi dengan jumlah yang memberi bobot, dengan catatan jika yang memberi bobot 0 maka tidak dimasukkan ke dalam perhitungan (Calhoun dan Campbell, 1985).

Kemudian, setelah mendapatkan nilai kritis setiap jenis barang, akan dibuat analisis ABC indeks kritis yang digabungkan dengan jumlah pemakaian, nilai investasi, dan nilai kritis.Menurut Calhoun dan Campbell, penggabungannya aalah sebagai berikut:

Indeks kritis $=$ jumlah pemakaian + jumlah investasi $+2 \mathrm{x}$ nilai kritis

Setelah mendapatkan nilai indeks kritis, barang akan dikelompokkan menjadi :

- Kelompok A memiliki nilai indeks kritis: $9.5-12.0$

- Kelompok B memiliki nilai indeks kritis: $6.5-9.4$

- Kelompok A memiliki nilai indeks kritis: $4.0-6.4$.

Kelebihan yang dimiliki oleh analisis $\mathrm{ABC}$ indeks kritis dari analisis $\mathrm{ABC}$ dalam pengendalian persediaan adalah analisis ini melibatkan pengguna sehingga kekritisan setiap jenis persediaan barang habis pakai dapat diketahui dengan pasti. Dengan demikian barang persediaan yang nilainya rendah akan tetapi sebenarnya kritis dalam penggunaan aktifitas kerja di program Vokasi UI akan tetap diperhatikan. Kekurangan dari analisis indeks kritis adalah membutuhkan waktu yang lama untuk memperoleh data (untuk penelitian ini menggunakan data selama tahun 1 tahun, terhitung mulai bulan Januari - Desember 2014) (Calhoun dan Campbell, 1985).

\section{METODE}

Metode yang digunakan dalam penelitian ini adalah metode deskriptif analisis. Penelitian dengan metode deskriptif analisis menurut Sugiyono (2008) merupakan metode 
penelitian dengan cara mengumpulkan data sesuai dengan yang sebenarnya kemudian data-data tersebut disusun, diolah dan dianalisis untuk dapat memberikan gambaran mengenai masalah yang ada. Jenis pendekatan yang digunakan adalah pendekatan studi kasus, yaitu dengan melihat permasalahan yang dihadapai oleh Bagian Pengadaan Program Vokasi UI dalam mengelola persediaan barang habis pekai (peralatan kantor) selama tahun 2014.
Pengadaan Program Vokasi Universitas Indonesia yang berlokasi di Gedung Program Vokasi, Kampus Universitas Indonesia, Depok. Populasi dalam penelitian ini ada 2 jenis, yaitu ada dua, yaitu: populasi pertama, adalah persediaan barang habis pakai (peralatan kantor) di Program Vokasi UI. Sampelnya adalah 160 jenis persediaan barang habis pakai (peralatan kantor) yang digunakan oleh seluruh pengguna di Program Vokasi UI untuk transaksi yang terjadi selama kurun waktu Januari 2014 - Desember 2014.

Tabel 1. Matriks Informan

\begin{tabular}{|l|l|}
\hline Informan & Data yang Didapatkan \\
\hline $\begin{array}{l}\text { Kasubag Pengadaan dan } \\
\text { Tenaga Kerja }\end{array}$ & $\begin{array}{l}\text { Tenaga, anggaran, barang } \\
\text { yang dipesan, jumlah } \\
\text { pemesanan, waktu } \\
\text { pemesanan, pengendalian } \\
\text { persediaan. }\end{array}$ \\
\hline $\begin{array}{l}\text { Staf pencatatan transaksi } \\
\text { pembelian dan permintaan } \\
\text { persediaan barang habis } \\
\text { pakai }\end{array}$ & $\begin{array}{l}\text { Barang yang dibeli, barang } \\
\text { yang diminta, jumlah barang } \\
\text { yang diminta, sistem } \\
\text { pencatatan }\end{array}$ \\
\hline
\end{tabular}

Data yang diperoleh pada penelitian ini akan diolah, dianalisis, dan diproses dengan menggunakan metode klasifikasi ABC untuk mendapatkan gambaran mengenai permintaan persediaan barang habis pakai di Program Vokasi UI serta nilai investasi yang dikeluarkan untuk persediaan barang habis pakai tersebut. Dengan demikian akan didapatkan klasifikasi barang sesuai dengan jenisnya, yaitu barang yang memiliki nilai tinggi, sedang, dan rendah. Selanjutnya gambaran tersebut diperdalam dengan menggunakan analisis indeks kritis ABC. Penelitian ini dilakukan dengan obyek Bagian
Populasi kedua adalah seluruh staf Bagian Pengadaan dan Tenaga Kerja Program Vokasi UI. Sampelnya adalah staf Bagian Pengadaan dan Tenaga Kerja yang terlibat dalam transaksi pembelian persediaan barang habis pakai dan pengolahan permintaan persediaan barang habis pakai di Program Vokasi UI. Staf yang mengurus masalah ini berjumlah 2 orang. Data yang digunakan dalam penelitian ini adalah data primer dan data sekunder. Data primer, dikumpulkan dengan cara melakukan wawancara mendalam dengan informan. Wawancara dilakukan oleh penulis dan dilakukan pencatatan atas jawaban 
informan. Pemilihan informan berdasarkan keterkaitan dan pemahaman yang mendalam tehadap pengendalian persediaan barang habis pakai di Bagian Pengadaan Program Vokasi UI.

Data sekunder, dikumpulkan dengan menggunakan dokumen pencatatan transaksi pembelian dan permintaan persediaan barang habis pakai di Program Vokasi UI selama kurun waktu dari bulan Januari 2014 Desember 2014.

Data yang telah diperoleh oleh penulis kemudian diperiksa kelengkapannya. Pengolahan data persediaan barang habis pakai dilakukan dengan menggunakan Microsoft Excel. Berikut ini adalah langkahlangkah yang dilakukan oleh penulis dalam melakukan analisis ABC pemakaian, analisis $\mathrm{ABC}$ nilai invenstasi, dan analisis $\mathrm{ABC}$ indeks nilai kritis. Pada penelitian ini, pemakaian persediaan barang habis pakai diganti dengan permintaan persediaan barang habis pakai, dengan asumsi bahwa pengguna persediaan barang habis pakai di seluruh Program Vokasi UI melakukan permintaan persediaan barang habis pakai untuk langsung digunakan.

Langkah-langkah untuk melakukan analisis ABC Permintaan

1. Membuat daftar permintaan untuk seluruh persediaan barang habis pakai (peralatan kantor) selama periode Januari Desember 2015.

2. Memasukkan kuantitas permintaan persediaan barang habis pakai, kemudian membuat rata-rata permintaan persediaan barang habis pakai.

3. Mengurutkan data tabel berdasarkan rata-rata permintaan persediaan barang habis pakai mulai dari permintaan terbesar hingga terkecil.

4. Menghitung persentase rata-rata permintaan setiap item persediaan barang habis pakai dari jumlah permintaan total.

5. Menghitung persentase kumulatif setiap permintaan item persediaan barang habis pakai.

6. Mengelompokkan persediaan barang habis pakai berdasarkan persentase kumulatif permintaan persediaan barang habis pakai. Permintaan persediaan barang habis pakai yang mempunyai kumulatif hingga $80 \%$ diklasifikasikan sebagai kelompok A, $80 \%$ - $95 \%$ diklasifikasikan sebagai kelompok $\mathrm{B}$, dan $95-100 \%$ diklasifikasikan sebagai kelompok C.

Langkah-langkah untuk melakukan analisis ABC Nilai Investasi:

1. Membuat daftar permintaan untuk seluruh persediaan barang habis pakai (peralatan kantor) selama periode Januari - Desember 2015.

2. Memasukkan kuantitas permintaan persediaan barang habis pakai, kemudian membuat rata-rata permintaan persediaan barang habis pakai. 
3. Memasukkan harga beli persediaan barang habis pakai, kemudian membuat rata-rata harga beli persediaan barang habis pakai.

4. Mengkalkulasikan nilai investasi dengan mengalikan rata-rata permintaan persediaan barang habis pakai dengan nilai rata-rata harga beli persediaan barang habis pakai.

5. Menghitung persentase nilai investasi setiap item persediaan barang habis pakai dari nilai investasi total semua persediaan.

6. Menghitung persentase kumulatif setiap permintaan item persediaan barang habis pakai.

7. Mengelompokkan persediaan barang habis pakai berdasarkan persentase kumulatif nilai investasi persediaan barang habis pakai. Nilai investasi persediaan barang habis pakai yang mempunyai kumulatif hingga $80 \%$ diklasifikasikan sebagai kelompok A, $80 \%$ - 95\% diklasifikasikan sebagai kelompok B, dan $95-100 \%$ diklasifikasikan sebagai kelompok C.

Langkah-langkah untuk melakukan analisis $\mathrm{ABC}$ nilai kritis:

1. Membuat daftar seluruh persediaan barang habis pakai yang digunakan oleh Program Vokasi UI selama periode Januari - Desember 2015.

2. Memasukkan bobot nilai kritis yang diberikan oleh setiap responden, yaitu $\mathrm{X}=3, \mathrm{Y}=2, \mathrm{Z}=1$, dan $\mathrm{O}=0$.

3. Menghitung rata-rata nilai kritis untuk setiap item persediaan barang habis pakai.
Apabila responden memberikan nilai $\mathrm{O}$, maka tidak diikutsertakan dalam penghitungan nilai kritis.

Langkah-langkah untuk melakukan analisis ABC indeks kritis:

Analisis $\mathrm{ABC}$ indeks kritis dapat diperoleh setelah mendapatkan nilai analisis $\mathrm{ABC}$ permintaan, analisis $\mathrm{ABC}$ investasi, dan analisis $\mathrm{ABC}$ nilai kritis.

1. Membuat daftar gabungan dari nilai analisis $\mathrm{ABC}$ permintaan, investasi, dan nilai kritis.

2. Membandingkan hasil yang diperoleh dari analisis $\mathrm{ABC}$ permintaan, nilai investasi, dan analisis $\mathrm{ABC}$ nilai kritis.

3. Melakukan pengelompokkan persediaan dengan ketentuan : persedian barang habis pakai akan dikelompokkan ke kelompok A jika memiliki nilai indeks kritis antara 9,5 - 12, kelompok B jika memiliki nilai indeks kritis antara 6,5 9,4 dan kemlompok C jika memiliki nilai indeks kritis antara $4-6,4$.

Penyimpanan Persediaan Barang Habis Pakai Prosedur untuk penyimpanan barang persediaan habis pakai yang memenuhi aturan adalah:

- Penyimpanan barang persediaan habis pakai seharusnya dilakukan oleh fungsi gudang. Fungsi gudang adalah menjaga barang dan terpisah dari fungsi penerimaan. 
- Barang yang disimpan harus sesuai dengan laporan penerimaan persediaaan barang habis pakai.

- Barang disimpan dan dikelompokan menurut jenis, ukuran, sifat persediaan yang dimiliki Program Vokasi UI.

- Barang yang masuk dan keluar harus dicatat dalam kartu gudang dan dilakukan oleh fungsi gudang.

\section{HASIL DAN PEMBAHASAN}

Pada Program Vokasi UI, persediaan barang habis pakai dikelola oleh Bagian Pengadaan dan Tenaga Kerja. Saat ini, menurut data hasil wawancara, jumlah sumber daya manusia yang ada di Bagian Pengadaan dan Tenaga Kerja sudah sesuai dengan beban kerja yang ada.

Perencanaan persediaan barang habis pakai (peralatan kantor) di Program Vokasi UI untuk tahun 2014 dilakukan setahun sekali dan disesuaikan dengan kebutuhan rutin. Pada pelaksanaannya, adakalanya terdapat beberapa persediaan yang dipesan yang tidak terdapat dalam daftar persediaan barang habis pakai Program Vokasi UI. Atas pembelian persediaan yang tidak terdapat dalam daftar persediaan tersebut, staf Bagian Pengadaan dan Tenaga Kerja yang mengelola persediaan akan memasukkan data tersebut sebagai item baru persediaan pada sistem informasi pengelolaan persediaan UI untuk Program Vokasi UI, yaitu SIMAK Persediaan.

Jumlah persediaan barang habis pakai yang dipesan ditentukan sesuai data permintaan (pada penelitian ini permintaan dianggap sama dengan pemakaiam karena persediaan barang habis pakai yang diminta oleh pengguna akan segera dipakai begitu barang diterima) dan pemesanan rutin dari tahuntahun sebelumnya. Anggaran untuk pembelian persediaan barang habis pakai Program Vokasi UI sudah dialokasikan untuk setiap bulannya berdasarkan kebutuhan rutin tahun-tahun sebelumnya.

Waktu pemesanan persediaan barang habis pakai Program Vokasi UI dilakukan berdasarkan kebutuhan rutin tahun-tahun sebelumnya. Selain itu juga dilihat berdasarkan jumlah stock di gudang.

Pencatatan persediaan dilakukan dengan menggunakan sistem informasi untuk pengelolaan persediaan dari Universitas Indonesia, yaitu SIMAK Persediaan. Sedangkan untuk mencatatan permintaan rutin dari seluruh pengguna di Program Vokasi UI dilakukan dengan menggunakan sistem pengelolaan persediaan yang dibuat dengan Microsoft Access. Sistem pencatatan persediaan pada SIMAK Persediaan sudah berjalan dengan baik begitu pula sistem pencatatan untuk permintaan internal dari seluruh peengguna di Program Vokasi UI, hanya saja sistem ini masih memiliki kekurangan, yaitu tidak dapat menampilkan jumlah stock awal dan jumlah stock akhir. Selain itu sistem pencatatan persediaan internal ini juga tidak dapat menampilkan data laporan pengambilan barang.

Bagian Pengadaan dan Tenaga Kerja Program Vokasi UI telah melakukan usahausaha sebagai berikut untuk melakukan 
pengendalian persediaan:

- Mengecek data persediaan secara fisik (stock opname) dan catatan sebanyak beberapa kali dalam sebulan. Jika terdapat barang yang kurang maka staf operator akan membuat pengajuan/ permintaan untuk pembelian persediaan.

- Melaksanakan prosedur permintaan dan pembelian persediaan sesuai dengan prosedur yang telah ditetapkan, termasuk pencatatan transaksi permintaan persediaan barang habis pakai dari seluruh pengguna di Program Vokasi UI dan transaksi pembelian.

- Melakukan pemberian prioritas untuk persediaan tertentu. Pemberian prioritas diberikan dalam hal diutamakan pemesanannya karena sifat persediaan yang dianggap penting seperti tinta printer dan kertas.

- Merekonsiliasi data permintaan yang diolah dengan sistem pengelolaan persediaan internal Program Vokasi UI dengan data yang diolah dengan SIMAK Persediaan UI.

Menurut Waters (dalam Atmaja, 2012), terdapat beberapa hal yang menjadi perhatian dalam pengendalian persediaan, yaitu persediaan apa saja yang harus disediakan, berapa jumlah persediaan yang harus dipesan, dan kapan persediaan harus dipesan. Untuk persediaan barang habis pakai Program Vokasi UI berikut ini adalah hal-hal yang harus diperhatikan, yaitu:

1. Persediaan barang habis pakai yang harus disediakan. Perencanaan kebutuhan barang persediaan habis pakai yang akan dipesan oleh Bagian Pengadaan dan Tenaga Kerja Program Vokasi UI dilakukan berdasarkan kebutuhan akan persediaan barang habis pakai tahuntahun sebelumnya dan dengan melihat ketersediaan persediaan barang habis pakai tersebut di Gudang Persediaan Program Vokasi UI. Karena aktifitas operasional Program Vokasi sebagai institusi pendidikan dari tahun ke tahun sudah tersusun secara rutin, maka perencanaan kebutuhan dengan cara demikian sudah cukup memadai.

2. Berapa banyak persediaan barang habis pakai yang harus dipesan. Jumlah persediaan yang dipesan ditentukan dengan menggunakan data pemesanan persediaan barang habis pakai tahun-tahun sebelumnya serta dengan melihat sisa persediaan barang habis pakai yang ada di gudang dan catatan persediaan barang habis pakai Program Vokasi UI. Selain itu juga dengan melihat alokasi anggaran yang telah dibuat pada RKAT untuk tahun berjalan. Langkah ini sangat baik. Penetapan alokasi anggaran ini penting untuk dilakukan dalam memulai suatu kegiatan ekonomi. Anggaran untuk persediaan barang habis pakai diperlukan untuk menghitung 
investasi dalam persediaan.

3. Kapan harus dilakukan pemesanan persediaan barang habis pakai. Metode pengendalian persediaan barang habis pakai yang digunakan oleh Bagian Pengadaan dan Tenaga Kerja Program Vokasi UI adalah metode periodik, yaitu dengan cara petugas bagian Pengadaan dan Tenaga Kerja menghitung sisa stok barang sebulan sekali kemudian dibandingkan dengan jumlah stok yang harus ada. Metode ini cocok untuk barang dengan jumlah permintaan yang tinggi dan memiliki nilai yang rendah. Akan tetapi untuk barang-barang yang bernilai tinggi lebih cocok dengan metode perpetual, karena paling efisien. Dengan metode ini semua data persediaan dimasukkan ke dalam sistem komputer dan setiap ada permintaan barang maka akan berkurang secara otomatis. Penulis sudah memperbaiki kekurangan pada sistem pengelolaan persediaan internal Program Vokasi UI dengan menampilkan data persediaan akhir setiap kali terjadi pencatatan transaksi atas permintaan persediaan barang habis pakai oleh pengguna, membuat laporan transaksi permintaan persediaan barang habis pakai harian (laporan status harian), laporan transaksi permintaan persediaan barang habis pakai per pengguna, serta laporan persediaan barang habis pakai yang paling banyak diminta, sedang, atau paling sedikit diminta pengguna. Laporan lain yang ditambahkan adalah pada aplikasi ini adalah daftar klasifikasi persediaan berdasarkan Analisis ABC permintaan, nilai investasi, dan indeks kritis dari tahun 2014 sebagai data acuan untuk tahun-tahun selanjutnya.

\begin{abstract}
Analisis ABC
Data persedian barang habis pakai di Program Vokasi UI selama periode Januari - Desember 2014 terdiri dari 160 item barang. Total persediaan sebanyak 160 item barang ini akan dikelompokkan berdasarkan analisis ABC permintaan, analisis $\mathrm{ABC}$ nilai investasi, dan analisis $\mathrm{ABC}$ indeks kritis.
\end{abstract}

\section{Kelompok Persediaan Barang Habis Pakai Berdasarkan Analisis ABC Permintaan}

Langkah-langkah yang telah dilakukan dalam melaksanakan analisis ABC permintaan adalah sebagai berikut:

1. Menghitung jumlah permintaan per tahun untuk setiap satuan unit barang.

2. Membuat daftar harga dari setiap barang tersebut.

3. Mengalikan permintaan dengan harga setiap barang untuk mendapatkan nilai investasi.

4. Mengurutkan nilai investasi dari yang terbesar hingga terkecil, setelah itu membuat persentase nilai investasi.

5. Menghitung nilai investasi kumulatif.

6. Mengelompokkan barang persediaan 
berdasarkan persentase nilai kumulatif.

7. Apabila nilai frekuensi kumulatifnya o sampai dengan $80 \%$ maka dikelompokkan sebagai A. Apabila berkisar antara $80-95 \%$ akan dikelompokkan sebagai B, dan apabila berkisar antara $95-100 \%$ akan dikelompokkan sebagai C.

8. Persediaan barang habis pakai yang masuk kelompok A diberi nilai 3, kelompok B diberi nilai 2, dan kelompok $\mathrm{C}$ diberi nilai 1.

Hasil analisis ABC nilai investasi seperti yang terlihat pada tabel 2 berikut ini.
Hasil perhitungan analisis ABC permintaan ditunjukkan pada tabel 2 di atas. Dari sini terlihat bahwa persediaan barang habis pakai yang masuk dalam kelompok A, memiliki jumlah permintaan sebesar 78,74\% dan hanya terdiri dari 9 item barang atau 5,63\% dari total persediaan barang habis pakai. Persediaan barang habis pakai yang masuk kelompok B, memiliki jumlah permintaan sebesar 16,15\% terdiri dari 26 item barang atau 16,25\% dari total persediaan barang habis pakai. Sedangkan persediaan barang habis pakai yang masuk kelompok C, memiliki jumlah permintaan sebesar 5,11\% terdiri dari 125 item barang atau 78,13\% dari total persediaan barang habis pakai.

Tabel 2 Hasil Analisis ABC Permintaan

\begin{tabular}{|c|c|c|c|c|}
\hline Kelompok & $\begin{array}{c}\text { Jumlah } \\
\text { Permintaan }\end{array}$ & $\begin{array}{c}\text { Persentase } \\
\text { Jumlah } \\
\text { Permintaan }\end{array}$ & $\begin{array}{c}\text { Jumlah } \\
\text { Barang Habis } \\
\text { Pakai }\end{array}$ & $\begin{array}{c}\text { Persentase Jumlah } \\
\text { Barang Habis } \\
\text { Pakai }\end{array}$ \\
\hline A & $2,103.67$ & $78.74 \%$ & 9 & $5.63 \%$ \\
\hline B & $4,31.42$ & $16.15 \%$ & 26 & $16.25 \%$ \\
\hline C & 136.58 & $5.11 \%$ & 125 & $78.13 \%$ \\
\hline Jumlah & $\mathbf{2 , 6 7 1 . 6 7}$ & $\mathbf{1 0 0 . 0 0 \%}$ & $\mathbf{1 6 0}$ & $\mathbf{1 0 0 . 0 0 \%}$ \\
\hline
\end{tabular}

Tabel 3 Kelompok A Analisis ABC Permintaan

\begin{tabular}{|c|l|}
\hline NO & \multicolumn{1}{|c|}{ NAMA BARANG } \\
\hline 1 & Amplop coklat folio Polos \\
\hline 2 & Amplop coklat A3 jaya \\
\hline 3 & Clear holder satuan PP pocket \\
\hline 4 & Map merk kabita/Roda \\
\hline 5 & Spidol Whiteboard \\
\hline 6 & Kertas HVS 70 gram uk. A4 \\
\hline 7 & Amplop Coklat A4 Polos \\
\hline 8 & Business file uk. Folio eagle \\
\hline 9 & Map merk diamond \\
\hline
\end{tabular}


Persediaan barang habis pakai yang masuk kelompok A dengan jumlah permintaan paling banyak perlu mendapat perhatian untuk selalu memiliki jumlah yang cukup agar tidak terjadi stock out saat pengguna meminta barang tersebut. Dengan demikian pelayanan terhadap pengguna tidak terhambat dan tidak mengganggu kegiatan operasional Program Vokasi UI terutama kegiatan belajar mengajar.

Dari tabel 3 di atas terlihat bahwa tinta printer meskipun dianggap persediaan yang penting ternyata tidak masuk dalam persediaan barang habis pakai dalam kelompok A tetapi masuk dalam kelompok C (lihat pada lampiranTabel Analisis ABC Permintaan). Hal ini disebabkan terjadinya sharing dalam penggunaan printer di Program Vokasi UI. Jika pengguna kehabisan tinta maka pengguna ini dapat menggunakan printer lain yang berada di Program Vokasi UI yang jarang digunakan untuk mencetak dan tidak langsung meminta tinta di Bagian Pengadaan dan Tenaga Kerja Program Vokasi UI. melaksanakan analisis $\mathrm{ABC}$ permintaan adalah sebagai berikut:

1. Menghitung jumlah permintaan per tahun untuk setiap satuan unit barang.

2. Membuat daftar harga dari setiap barang tersebut.

3. Mengalikan permintaan dengan harga setiap barang untuk mendapatkan nilai investasi.

4. Mengurutkan nilai investasi dari yang terbesar hingga terkecil, setelah itu membuat persentase nilai investasi.

5. Menghitung nilai investasi kumulatif.

6. Mengelompokkan barang persediaan berdasarkan persentase nilai kumulatif.

7. Apabila nilai frekuensi kumulatifnya 0 sampai dengan 80\% maka dikelompokkan sebagai A. Apabila berkisar antara $80-$ 95\% akan dikelompokkan sebagai B, dan apabila berkisar antara $95-100 \%$ akan dikelompokkan sebagai $\mathrm{C}$.

8. Persediaan barang habis pakai yang masuk kelompok A diberi nilai 3, kelompok B diberi nilai 2, dan kelompok C diberi nilai 1.

Tabel 4 Hasil Analisis ABC Nilai Investasi

\begin{tabular}{|c|c|r|r|c|}
\hline Kelompok & $\begin{array}{c}\text { Jumlah } \\
\text { Persediaan Barang } \\
\text { Habis Pakai }\end{array}$ & $\begin{array}{c}\text { Persentase } \\
\text { Jumlah } \\
\text { Persediaan }\end{array}$ & Nilai Investasi & $\begin{array}{c}\text { Persentase } \\
\text { Nilai Investasi }\end{array}$ \\
\hline A & 11 & $6,88 \%$ & $19,052,866.37$ & $79.94 \%$ \\
\hline B & 67 & $41,88 \%$ & $3,588,770.36$ & $15.06 \%$ \\
\hline C & 82 & $51.25 \%$ & $1,192,969.43$ & $5.01 \%$ \\
\hline Jumlah & 160 & $100.00 \%$ & $23,834,606.16$ & $100.00 \%$ \\
\hline
\end{tabular}

Kelompok Persediaan Barang Habis Pakai

Berdasarkan Analisis ABC Nilai Investasi

Langkah-langkah yang telah dilakukan dalam
Hasil perhitungan analisis nilai investasi ditunjukkan pada tabel 4 di atas. Dari sini terlihat bahwa persediaan barang habis pakai 
yang masuk dalam kelompok A, memiliki nilai investasi sebesar $79,94 \%$ dan hanya terdiri dari 18 item barang atau $11,25 \%$ dari total persediaan barang habis pakai. Persediaan barang habis pakai yang masuk kelompok B, memiliki nilai investasi sebesar 15,06\% terdiri dari 29 item barang atau 18,13\% dari total persediaan barang habis pakai. Sedangkan persediaan barang habis pakai yang masuk kelompok $\mathrm{C}$, memiliki nilai investasi sebesar 5,01\% terdiri dari 113 item barang atau $70,63 \%$ dari total persediaan barang habis pakai. Persediaan barang habis pakai yang masuk kelompok A dengan jumlah investasi paling banyak perlu mendapat perhatian khusus dari manajemen dalam hal pengendaliannya. Besarnya investasi yang dikeluarkan akan mengakibatkan biaya penyimpanan persediaan yang besar dan juga kerugian yang besar jika persediaan tersebut mengalami kerusakan.

Tabel 5 Kelompok A Analisis ABC Nilai Investasi

\begin{tabular}{|c|l|}
\hline No. & \multicolumn{1}{|c|}{ Nama Barang } \\
\hline 1 & Kertas HVS 70 gram uk. A4 \\
\hline 2 & Tinta Printer 12A (laserjet hp Q2612A) \\
\hline 3 & Tinta riso master type S-4370 \\
\hline 4 & Tinta Riso Ink RZ type S-4251 \\
\hline 5 & Tinta Printer 35A (laserjet hp CB2635A) \\
\hline 6 & Kertas Bergaris (LJU) \\
\hline 7 & Tinta Printer 13A (laserjet hp Q2613A) \\
\hline 8 & Plakat \\
\hline 9 & Tinta Printer 85A (laserjet hp CE 285A) \\
\hline 10 & Spidol Whiteboard \\
\hline 11 & Tinta Printer 53A (laserjet hp Q7553A) \\
\hline 12 & Kertas HVS 70 gram uk. F4 \\
\hline 13 & Ordner besar bantex \\
\hline 14 & Kertas A4 70 gram Kop \\
\hline 15 & Seminar Kit \\
\hline 16 & Tinta Printer 06F (laserjet hp C 9306F) \\
\hline 17 & Amplop coklat A3 jaya \\
\hline 18 & Amplop coklat folio Polos \\
\hline
\end{tabular}

Penggunaan analisis ABC akan menghasilkan pengendalian yang lebih baik bagi Program Vokasi UI karena memungkinkan perlakuan kontrol selektif pada setiap kelompok persediaan. Selain itu analisis ABC juga dapat mengurangi biaya dengan memprioritaskan perlakuan pada kelompok tertentu dan serta dapat meningkatkan pelayanan. Dengan analisis ABC ini Program Vokasi UI dapat menyediakan jenis persediaan serta jumlah persediaan yang tepat.

Kelompok Persediaan Barang Habis Pakai Berdasarkan Analisis ABC Indeks Kritis

Analisis ABC nilai kritis dapat diperoleh setelah mendapatkan nilai analisis $\mathrm{ABC}$ permintaan, analisis $\mathrm{ABC}$ investasi, dan analisis $\mathrm{ABC}$ nilai kritis.

Langkah-langkah yang dilakukan dalam untuk memperoleh nilai kritis adalah sebagai berikut:

1. Membuat daftar seluruh persediaan barang habis pakai yang digunakan oleh Program Vokasi UI selama periode Januari - Desember 2015.

2. Memasukkan bobot nilai kritis yang diberikan oleh setiap responden, yaitu $\mathrm{X}=3, \mathrm{Y}=2, \mathrm{Z}=1$, dan $\mathrm{O}=0$.

3. Menghitung rata-rata nilai kritis untuk setiap item persediaan barang habis pakai. Apabila responden memberikan nilai $\mathrm{O}$, maka tidak diikutsertakan dalam penghitungan nilai kritis.

Kemudian Analisis ABC indeks kritis dapat diperoleh setelah mendapatkan nilai analisis $\mathrm{ABC}$ permintaan, analisis $\mathrm{ABC}$ investasi, dan analisis $\mathrm{ABC}$ nilai kritis. Langkah-langkah yang dilakukan adalah : 
1. Membuat daftar gabungan dari nilai analisis $\mathrm{ABC}$ permintaan, investasi, dan nilai kritis.

2. Membandingkan hasil yang diperoleh dari analisis $\mathrm{ABC}$ permintaan, nilai investasi, dan analisis ABC nilai kritis.

3. Melakukan pengelompokkan persediaan dengan ketentuan : persedian barang habis pakai akan dikelompokkan ke kelompok A jika memiliki nilai indeks kritis antara 9,5 - 12, kelompok B jika memiliki nilai indeks kritis antara 6,5 9,4 dan kemlompok $\mathrm{C}$ jika memiliki nilai indeks kritis antara $4-6,4$. yang masuk dalam kelompok $\mathrm{C}$ terdiri dari 82 item persediaan barang habis pakai dan menggunakan investasi sebesar 5,01\%.

Persediaan barang habis pakai yang masuk pada kelompok A memiliki nilai kritis tertinggi dalam pelayanan kepada pengguna dan perlu mendapat perhatian khusus dalam hal pengendalian.

Pengendalian yang diterapkan terhadap setiap kelompok persediaan barang habis pakai berbeda. Persediaan barang habis pakai yang masuk kelompok A memerlukan pengendalian yang ketat dan dapat dilakukan oleh pimpinan puncak Program Vokasi.

Tabel 6 Hasil Analisis ABC Indeks Kritis

\begin{tabular}{|c|c|r|r|c|}
\hline Kelompok & $\begin{array}{c}\text { Jumlah } \\
\text { Persediaan Barang } \\
\text { Habis Pakai }\end{array}$ & $\begin{array}{c}\text { Persentase } \\
\text { Jumlah } \\
\text { Persediaan }\end{array}$ & Nilai Investasi & $\begin{array}{c}\text { Persentase } \\
\text { Nilai Investasi }\end{array}$ \\
\hline A & 11 & $6,88 \%$ & $19,052,866.37$ & $79.94 \%$ \\
\hline B & 67 & $41,88 \%$ & $3,588,770.36$ & $15.06 \%$ \\
\hline C & 82 & $51.25 \%$ & $1,192,969.43$ & $5.01 \%$ \\
\hline Jumlah & $\mathbf{1 6 0}$ & $\mathbf{1 0 0 . 0 0 \%}$ & $\mathbf{2 3 , 8 3 4 , 6 0 6 . 1 6}$ & $\mathbf{1 0 0 . 0 0 \%}$ \\
\hline
\end{tabular}

Hasil perhitungan analisis $\mathrm{ABC}$ indeks kritis ditunjukkan pada tabel 4 di atas. Dari sini terlihat bahwa $6,88 \%$ dari persediaan barang habis pakai yang masuk dalam kelompok A terdiri dari 11 item persediaan barang habis pakai dan menggunakan investasi sebesar $79,94 \%$. selanjutnya $41,88 \%$ dari persediaan barang habis pakai yang masuk dalam kelompok B terdiri dari 67 item persediaan barang habis pakai dan menggunakan investasi sebesar 15,06\%. Dan yang terkahir, $51,25 \%$ dari persediaan barang habis pakai
Perencanaan persedian barang habis pakai yang msuk dalam kelompok A ini harus akurat. Pengendalian/kontrol atas persediaan kelompok ini dapat dilakukan paling tidak seminggu sekali. Program Vokasi UI dapat menambah jumlah suplier untuk memastikan ketersediaan persediaan barang habis pakai pada saat terjadi permintaan oleh pengguna.

Persediaan barang habis pakai yang masuk kelompok B memerlukan pengendalian secara moderate dan dapat dilakukan oleh pimpinan tingkat menengah Program Vokasi. 
Pengendalian/kontrol atas persediaan dan nilai kritis tinggi.

kelompok ini dapat dilakukan sebulan sekali.

Tabel 7 Kelompok A Analisis ABC Indeks

\begin{tabular}{|c|l|}
\hline No & \multicolumn{1}{|c|}{ Nama Barang } \\
\hline 1 & Clear holder satuan PP pocket \\
\hline 2 & Kertas A4 70 gram Kop \\
\hline 3 & Kertas Bergaris (LJU) \\
\hline 4 & Plakat \\
\hline 5 & Amplop coklat A3 jaya \\
\hline 6 & Amplop coklat folio Kop \\
\hline 7 & Amplop coklat folio Polos \\
\hline 8 & Kertas HVS 70 gram uk. A4 \\
\hline 9 & Piagam \\
\hline 10 & Seminar Kit \\
\hline 11 & Spidol Whiteboard \\
\hline
\end{tabular}

Tabel 8 Persediaan Barang Habis Pakai dengan Nilai Permintaan Tinggi, Nilai Investasi Tinggi, dan Nilai Kritis Rendah Kritis

\begin{tabular}{|c|l|}
\hline No & Nama Barang \\
\hline 1 & Amplop coklat A3 jaya \\
\hline 2 & Amplop coklat folio Polos \\
\hline 3 & Kertas HVS 70 gram uk. A4 \\
\hline 4 & Seminar Kit \\
\hline 5 & Spidol Whiteboard \\
\hline
\end{tabular}

Untuk kelompok B ini, perencanaan dapat menggunakan data penggunaan tahun lalu pada periode yang sama. Pengendalian terhadap persediaan barang habis pakai yang masuk kelompok C longgar dan dapat dilakukan tiga bulan sekali. Pengendalian dapat dilakukan oleh departemen pengguna.

Kelompok data berikut ini diperoleh pada saat melakukan penggabungan antara nilai permintaan, nilai investasi, dan indeks kritis.

1. Persediaan barang habis pakai dengan nilai permintaan tinggi, nilia investasi tinggi,
2. Pengendalian terhadap persediaan barang habis pakai pada kelompok ini harus ketat karena ketidaktersediaan persediaan akan menyebabkan kegiatan operasional pada Program Vokasi terganggu khususnya kegiatan belajar mengajar.

3. Persediaan barang habis pakai dengan nilai permintaan tinggi, nilia investasi tinggi, dan nilai kritis rendah. Ketersediaan persediaan barang habis pakai yang masuk kelompok ini tidak harus ada karena nilai kritisnya rendah, oleh sebab 
itu dapat diganti dengan persediaan

lainnya.

4. Persediaan barang habis pakai ini sebaiknya disediakan oleh bagian Pengandaan dan Tenaga Kerja Program Vokasi UI karena jumlah permintaan serta nilai investasinya tinggi sehingga jika stok persediaan kelompok ini tidak tersedia akan menyebabkan kerugian.

\section{PENUTUP}

Simpulan

Tujuan dari penelitian ini adalah untuk mengetahui pengendalian persediaan barang di Program Vokasi Universitas Indonesia dan persediaan barang yang menjadi kelompok kelompok A, B, dan C berdasarkan analisis ABC pemakaian, investasi, dan indeks kritis. Penelitian menggunakan metode deskriptif analisis.

Tabel 9 Persediaan Barang Habis Pakai dengan Nilai Permintaan Rendah, Nilai Investasi Rendah, dan Nilai Kritis Rendah

\begin{tabular}{|l|l|}
\hline No & Nama Barang \\
\hline 1 & Bak Stempel \\
\hline 2 & Tinta Stempel \\
\hline 3 & Stempel \\
\hline
\end{tabular}

5. Persediaan barang habis pakai dengan nilai permintaan rendah, nilai investasi rendah, dan nilai kritis tinggi. Persediaan barang habis pakai yang masuk kelompok ini meskipun jumlah permintaan serta harganya rendah tetapi harus disediakan, jika tidak dapat mengganggu kelancaran proses belajar mengajar di Program Vokasi UI.

6. Persediaan barang habis pakai dengan nilai permintaan rendah, nilia investasi rendah, dan nilai kritis rendah. Pemesanan persediaan barang habis pakai yang masuk kelompok ini dapat dihilangkan karena sudah tidak digunakan lagi. untuk melihat permasalahan yang dihadapi dan aktivitas yang dilakukan oleh Bagian Pengadaan Program Vokasi UI dalam mengelola persediaan barang habis pakai selama tahun 2014. Penelitian ini juga akan menghasilkan aplikasi yang digunakan untuk mengelola persediaan barang habis pakai di Program Vokasi UI.

Dari hasil penelitian dapat diambil beberapa kesimpulan, yaitu:

1. Pengendalian persediaan barang habis pakai pada yang dilakukan oleh Bagian Pengadaan dan Tenaga Kerja Program Vokasi UI pada dasarnya sudah dilakukan secara optimal. Hal ini dapat dilihat dari: 
- Perencanaan persediaan dapat dilakukan dengan baik dengan melihat kebutuhan tahun-tahun sebelumnya.

- Jumlah pesanan persediaan barang habis pakai ditentukan dengan menggunakan data pemesanan persediaan barang habis pakai tahuntahun sebelumnya serta dengan melihat sisa persediaan barang habis pakai yang ada di gudang dan catatan persediaan barang habis pakai Program Vokasi UI yang ada di Bagian Pengadaan dan Tenaga Kerja.

- Pencatatan persediaan sudah dilakukan dengan menggunakan SIMAK Persediaan. Sedangkan untuk mencatatan permintaan rutin dari seluruh pengguna di Program Vokasi UI dilakukan dengan menggunakan sistem pengelolaan persediaan yang dibuat dengan Microsoft Access. Penulis sudah memperbaik kekurangan dari sistem pengelolaan persediaan internal.

2. Dari hasil analisis $\mathrm{ABC}$ permintaan didapat bahwa kategori persediaan barang habis pakai yang masuk dalam kelompok A adalah sebanyak 9 item, kelompok B sebanyak 26 item, dan kelompok C sebanyak 125 item. Sebanyak $78,74 \%$ permintaan berasal hanya dari 9 item barang dan 5,11\% permintaaan berasal dari 125 item barang.

3. Dari hasil analisis ABC nilai investasi didapat bahwa kategori persediaan barang habis pakai yang masuk dalam kelompok A adalah sebanyak 18 item, kelompok B sebanyak 29 item, dan kelompok C sebanyak 113 item. Sebanyak $79,94 \%$ nilai investasi hanya diberikan untuk 18 item barang dan 5,01\% nilai investasi diberikan untuk 113 item barang.

4. Dari hasil analisis ABC indeks kritis didapat bahwa sebanyak 11 item persediaan barang habis pakai yang masuk kelompok A memiliki nilai investasi sebesar 79,94\%, 67 item persediaan barang habis pakai yang masuk kelompok B memiliki nilai investasi sebesar $15,06 \%$, dan 82 item persediaan barang habis pakai yang masuk kelompok $\mathrm{C}$ memiliki nilai investasi sebesar 5,01\%.

5. Pengendalian persediaan di tempat penyimpanan sudah memadai. Hal ini dapat dilihat dari pemisahan tugas yang sudah dilakukan antara pegawai yang memesan barang, menerima, dan melakukan penyimpanan. Persediaan barang habis pakai juga sudah disimpan dengan dikelompokkan berdasarkan jenisnya. Hanya saja ruangs tempat penyimpanan barang habis pakai dirasa masih kurang mengingat terdapat selain persediaan barang habis pakai juga disimpan di tempat yang sama.

Hasil penelitian ini dapat digunakan oleh 
Program Vokasi UI untuk memperbaiki pengendalian persediaan barang habis pakai di Program Vokasi UI. Pengendalian terhadap persediaan barang habis pakai harus disesuaikan dengan kelompok/klasifikasi persediaan barang habis pakai tersebut sehingga tujuan pengendalian atas persediaan barang habis pakai dapat tercapai, yaitu dapat mengelola persediaan agar dapat memenuhi kebutuhan jumlah persediaan pada waktu yang tepat, serta jumlah biaya yang rendah.

\section{Saran}

Hasil penelitian ini diharapkan dapat meberikan saran kepada Program Vokasi umumnya dan khususnya bagian Pengadaan dan TenagaKerja untuk menggunakan aplikasi yang dapat memperlihatkan stock barang yang tersedia serta jumlah stock akhir sehingga dapat dengan cepat memantau persediaan yang ada. Selain itu juga diperlukan laporan yang dapat memperlihatkan transaksi permintaan barang berdasarkan pengguna, barang yang diminta serta jumlah transaksinya agar dapat dilakukan evaluasi terhadap pengelolaan persediaan barang habis pakai berdasarkan pengguna, jenis persediaan, serta jumlah kebutuhan persediaan barang habis pakai.
Penelitian lebih lanjut terhadap persediaan barang habis pakai di Program Vokasi UI dapat dilakukan untuk mendapatkan model yang tepat untuk mengelola persediaan barang habis pakai dalam jumlah yang tepat pada waktu yang tepat serta biaya yang minimum. Nantinya model ini dapat digunakan untuk mengevaluasi anggaran dan pemakaian aktual persediaan barang habis pakai.

\section{Ucapan Terima Kasih}

Ucapan terima kasih penulis ucapkan kepada Kasubag Pengadaan dan Tenaga Kerja beserta stafnya yang telah banyak memberikan bantuan dalam penelitian ini.

\section{DAFTAR PUSTAKA}

Assauri, Sofjan. 1999. Manajemen Produksi dan Operasi. Fakultas Ekonomi UI.

Calhoun, G.L., and Campbell, K.A. 1985. ABC and Critical Indexing. In Hand Book of Health Care Material Management.

Heizer, J., dan Render, B. 1999. Operations Management. 5th edition, Prentice-Hall.

Karuna Atmaja, Hermina. 2012. Penggunaan Analisis ABC Indeks Kritis untuk Pengendalian 
persediaan Obat Antibiotik di Rumah Sakit M.H. Thamrin Jakarta

Modul Kebijakan Akuntansi

Berbasis

Akrual.2015. https://mochram.files.wordpress.com/2014/10/3-materi-kaba-150414.pdf. 30 Juni.

Standar Akuntansi Pemerintahan Pernyataan No.05 Akuntansi Persediaan,.2015. http://www.ksap.org/standar/PSAP05.pdf. 30 Juni.

Implementasi Klasifikasi Persediaan pada Rumah Sakit Munggunakan Metode ABC-Fuzzy Classification. 2015. http://digilib.its.ac.id/public/ITS-Undergraduate-17675-5207100029Paper.pdf .30 Juni.

Pawitan, Gandi dan Paramasatya, Amithya. 2006. Aplikasi Analisis Pareto Dalam Pengendalian Inventori Bahan Baku Pada Bisnis Restoran, Jurnal Administrasi Bisnis Universitas Parahyangan (2008), Vol.4, No.1.

Rangkuti, Freddy. 2007. Manajemen Persediaan. Rajawali Pers. Jakarta

Rudianto. 2009. Penganggaran. Erlangga. Jakarta.

Schroeder, Goldstein and Rungtusanatham. 2010. Operations Management: Contemporary Concepts and Cases. 5th ed.. McGraw-Hill

Sugiono. 2008. Metode Penelitian Bisnis. Penerbit Alfabeta. Bandung. 